\title{
Krisis breekt uit: identiteit, politiek, cultuur
}

Gijs van Oenen

Krisis 40 (1): 26-35.

\begin{abstract}
Identity politics, like Krisis, has its origins in the early 1980s. This coincides with Michel Foucault's rejection of demands or claims of identity as 'to be left to the police'. In a strange but perhaps inevitable twist of fate, identity politics has later one become affiliated precisely with policing, leading to political correctness in which identity claims are both mandatory and subject to politically motivated censure. While initially in the service of emancipation, identity has thus become weaponized, which reflects an important shift in political and cultural sensitivities between the 1980s and the 2010s.
\end{abstract}

\section{Keywords}

Politics, Identity, Culture, Foucault, Emancipation

DOI

$\underline{10.21827 / \mathrm{krisis} .40 .1 .36973}$

\section{Licence}

This work is licensed under a Creative Commons Attribution-NonCommercial 3.0 License (CC BYNC 3.0). 


\section{Krisis breekt uit: identiteit, politiek, cultuur} Gijs van Oenen

Krisis brak 40 jaar geleden uit. Zoals je tegenwoordig break-out rooms hebt in Zoom, zo vormde Krisis destijds een break-out room in het ecosysteem van de filosofische tijdschriften. Ga samenzweren, kom terug met iets nieuws. Zoals iedere uitbraak van het nieuwe - zoals ieder avant-garde project - probeert de uitbreker ook hier enerzijds nieuw en vernieuwend te blijven, en anderzijds de mainstream te infecteren met deze aanstekelijke nieuwheid, zodat de nieuwe mutatie in de loop der jaren wellicht zal gaan behoren tot het vaste filosofiepakket waaraan we nolens volens periodiek worden blootgesteld. Als het tenminste niet voortijdig wordt geïsoleerd en gemarginaliseerd, zodat de filosofische populatie resistentie kan opbouwen tegen de nieuwe mutant en voort kan leven zoals weleer.

Zowel het ontstaan als succes van de uitbraak is dus gerelateerd aan de omstandigheden - het ecosysteem - waarin deze plaatsvindt. In deze bijdrage wil ik, grotendeels indirect maar daarom hopelijk niet minder sprekend, iets zeggen over Krisis aan de hand van een beschouwing over een andere crisis, waarvan de oorzaken rond de ontstaansperiode van Krisis te situeren zijn: de identiteitspolitiek, vandaag de dag uitmondend, of ontaardend, in politieke correctheid en - zoals ik zal betogen - identiteitspolitie. Dit alles door een, misschien wel onvermijdelijk, misbegrip van het werk van Michel Foucault.

Krisis debuteerde in 1980. Het begin van de jaren tachtig van de vorige eeuw was in meerdere opzichten een bijzondere tijd. Het begrip ideologie waarde nadrukkelijk rond in de intellectuele ether. Autobiografisch detail: in dat jaar volgde ik aan de UvA een cursus 'Ideologietheorie' bij Krisis-medeoprichtster Karen Vintges, de eerste en enige filosofiecursus die ik ooit volgde. Maar de ideologie werd ook militant gepraktiseerd, door een heel scala aan sociale bewegingen en actiegroepen: feminisme, de homobeweging, de kraakbeweging, de antikernenergiebeweging, en natuurlijk het communisme.

Dat ging er niet altijd zachtzinnig aan toe. Dat blijkt eind februari 1980, wanneer de ontruiming van het kraakpand gevestigd aan de Vondelstraat 72 in Amsterdam leidt tot een veldslag. Meer dan vijftig politieagenten raken gewond, straat en pand worden gebarricadeerd, en de vrijstaat wordt uitgeroepen - een illusie waaraan enkele dagen later door een colonne met gepantserde 
bulldozers een eind wordt gemaakt. Maar niet voor lang, want op 30 april vindt de inhuldiging van de nieuwe koningin plaats, aanleiding voor allerhande militante demonstraties in de hoofdstad, onder motto's als 'geen woning, geen koning' en 'kein Haus, kein Claus'. Er spelen zich chaotische strijdtaferelen af, de binnenstad raakt bezaaid met stenen, glas en bouwmateriaal en er vallen honderden gewonden. De toon is gezet voor de jaren tachtig: weg met de onschuld van de flowerpower en de praatgroepen. De nieuwe toon is hard, militant en onverzoenlijk.

Ruim tien jaar geleden schreef ik in De Witte Raaf, dat andere Nederlandstalige blad voor intellectuele cultuur, over deze ontwikkelingen aan het begin van de jaren tachtig (Van Oenen 2009). Ik typeerde ze als de 'verloren onschuld' van de radicale actiegroepen, met name de kraakbeweging, die begin jaren tachtig in de verleiding raakte om het gebruikte geweld van middel tot doel in zichzelf te laten uitgroeien. Actie en geweld waren min of meer ongemerkt tot vanzelfsprekend onderdeel van hun identiteit verworden. Wat dat betreft verschilden ze eigenlijk niet zo veel van hun schijnbare tegenstanders midden jaren tachtig: de rechtse politici die een draai bepleitten richting law and order, en dat pleit ook daadwerkelijk wonnen. Beide partijen vonden het tijd voor een harde aanpak en verbonden die aan hun nieuwverworven identiteit.

Nieuw verworven, want identiteit is een cruciale nieuwe speler in het veld van de jaren tachtig en later (Van Oenen 1999). Het is de geboortetijd van de identiteitspolitiek. Waar emanciperende mensen zichzelf al in de jaren zeventig - via een proces van collectieve sociale mobilisatie en bewustwording - zagen als drager van een 'identiteit', verbinden ze daaraan vanaf de jaren tachtig nu ook een politieke dimensie. Identiteit wordt een grond die je kunt aanroepen om politieke medestanders te werven, en politieke tegenstanders te bestrijden. Of, in het filosofische vocabulaire dat rond deze tijd veld wint: uit te sluiten. Hoewel natuurlijk de ideologische intentie juist de strijd tegen uitsluiting is: uitsluiting op grond van ras, gender, seksualiteit, etniciteit, religie, leeftijd, of - zoals artikel 1 van de Grondwet het even tautologisch als zelfondermijnend stelt - welke andere grond dan ook. Niet toevallig overigens stamt ook dit grondwetsartikel uit begin jaren tachtig, onze Achsenzeit.

Ik bedoel hier dus niet te betogen dat Krisis op de een of andere manier als een vehikel van identiteitspolitiek moet worden gezien, verre van dat. Het gaat mij erom dat zij is ontstaan in een filosofisch en ideologisch krachtenveld waarin de identiteitspolitiek net vorm en kracht 
begon te vinden. Wat in Krisis verscheen, verhoudt zich dus wel altijd tot dat krachtenveld. Ik denk zelfs dat Krisis, in het algemeen gesproken, er redelijk in is geslaagd zich rekenschap te geven van de identiteitspolitiek - of meer filosofisch academisch geformuleerd: de cultural studies - zonder zich er helemaal aan uit te leveren.

Dat brengt me bij wat ik als de lastigste kwestie van die vroege jaren tachtig zie - een kwestie die verbonden is met de identiteitspolitiek, maar daar op een curieuze manier toch ook helemaal aan tegengesteld is. Die kwestie is, simpel samengevat, het werk en de invloed van Michel Foucault. Uit vele surveys komt Foucault al jarenlang tevoorschijn als meest geciteerde auteur in de geesteswetenschappen. Het probleem dat ik hier wil bespreken, is dus zeker niet alleen het probleem van Krisis, maar dat van zo'n beetje alle tijdschriften in de geesteswetenschappen en de filosofie. Het zegt veel over de specifieke aard van een filosofisch tijdschrift - over de 'identiteit' ervan - hoe het met de kwestie Foucault is omgegaan. Dat hangt af van de specifieke omstandigheden waarin een tijdschrift zich begeeft: de nationale cultuur, de dominante filosofische opvattingen, en de culturele percepties van de redactieleden. In het geval van Krisis speelt, zou ik zeggen, die achtergrond in het roerige Amsterdam van begin jaren tachtig een duidelijke rol, gezien dat de oprichters en veel van de redactieleden uit de kring van de UvA en de Amsterdamse binnenstad afkomstig zijn.

Krisis is zeker niet het enige tijdschrift dat zich destijds op Foucault heeft gestort; minstens zozeer, zij het meer exegetisch, deed ook het Nijmeegse Te Elfder Ure dit. Maar in Krisis is wel geprobeerd om het werk van Foucault meer op sociale en culturele thematieken te betrekken (door accrediterende filosofiepolitie ook wel valselijk gecategoriseerd als 'toegepaste filosofie'). Ik zal niet proberen dit systematisch aan te tonen, maar meld alleen dat mijn eigen eerste publicatie in Krisis (Van Oenen 1984) een recensie betrof van L'Invention du social, het tweede boek van socioloog Jacques Donzelot (na La police des familles) die naar de Franse sociale verhoudingen keek vanuit het werk van Foucault. Vanuit het genealogische werk van Foucault, moet ik zeggen, want dat is hier het springende punt.

Foucault was al in de jaren zestig in Nederland ook al bekend en populair, maar dan vanuit de specifieke invalshoek van de antipsychiatrie. Zijn Folie et déraison uit 1961 werd, iets te gemakkelijk, gezien als ondersteuning van de kritiek die zich in de loop van de jaren zestig ontvouwde op de gevestigde psychiatrie, een kritiek die verder meer langs de lijnen van Marcuse, 
Laing, en in Nederland Jan Foudraine verliep. De Foucault die de ranglijsten van de geesteswetenschappen aanvoert is echter bovenal de latere, genealogische Foucault. Die Foucault manifesteert zich voor het eerst, bij vlagen, in L'ordre du discours, Foucaults inaugurele rede uit 1970. Of eigenlijk zien we al een vlaag, een schakel misschien zelfs tussen vroegere en latere Foucault, in zijn beroemde opmerking aan het einde van de introductie in Archéologie du savoir, die neer komt op: laat het vaststellen van onze identiteit maar aan de politie over.

Die opmerking past bij de militante, actievoerende Foucault van de eerste helft van de jaren zeventig - de Foucault die weliswaar een aanstelling heeft aan het Collège de France, bij uitstek een symbool van het academische establishment, maar zich tegelijkertijd solidariseert met radicale sociale bewegingen en, net als Sartre, de straat op gaat om de kritiek op de gevestigde orde kracht bij te zetten. Maar de opmerking past ook bij de Foucault van de late jaren zestig, die zich bovenal niet op een positie, op een 'auteurschap', wil laten vastleggen. Foucault wil niet kritisch zijn, anderen ongelijk geven, maar een 'blanke plaats creëren' van waaruit zijn discours zich kan vormen - een discours dat nog op veel punten onzeker is, zoals (dus) ook zijn eigen identiteit. Sterker nog, Foucault schrijft 'om geen gezicht te hebben', om het moment van het vaststellen van zijn identiteit uit te stellen - om uit handen te blijven van de politie.

Het probleem is dat die politie er gaandeweg toch is gekomen. Waarschijnlijk is dit ook onvermijdelijk - een dialectische noodzaak, in het door Foucault systematisch gemeden en bestreden hegeliaanse vocabulaire. In de jaren zeventig bestond nog een vorm van militant zijn die de vraag naar identiteit kon uitstellen, zwevende kon houden. Misschien ook juist omdat men er nog niet uit was, maar wel leefde, en handelde, in het vooruitzicht dat men er op termijn wel uit zou komen. Min of meer vergelijkbaar met wat tegenwoordig 'prefiguratief' heet. (Dat er tegenwoordig een speciale naam voor is, geeft al aan dat die ruimte er niet meer vanzelfsprekend is, maar geclaimd moet worden - een claim die zelf alweer problematisch is). Zo'n andere uitkomst had er wellicht ook wel kunnen komen - zou de genealogische beschouwing zeggen. Maar in feite nam de politieke cultuur een wending richting een vaste militante vorm; anders gezegd, die militante houding werd zelf een belangrijk onderdeel van de identiteit.

Naast de kraakbeweging was er nog een andere beweging die aan het begin van de jaren tachtig een militante vorm aannam: de homobeweging. Het werk van Foucault speelde hierbij ook een 
belangrijke rol. In het voetspoor van Freud had Foucault, in La volonté de savoir uit 1976, betoogd dat de moderne subjectiviteit zich primair vormt via discoursen rondom de seksualiteit. De moderne mens produceert zichzelf via zelfonderzoek en zelfbegrip, en spreekt daarover publiekelijk, bijvoorbeeld in romans. Deze reflectie brengt het innerlijke en intieme in nauw verband met seksualiteit: zij vermoedt dat de seksualiteit de sleutel biedt tot de complexe en tegenstrijdige innerlijkheid van de moderne mens. In plaats van duidelijkheid te bieden over zijn subjectiviteit of identiteit, is het spreken over seksualiteit echter tot gewoonte, of zelfs tot obsessie en doel op zich geworden, zoals de therapiegolf van de jaren zeventig heeft laten zien. De homobeweging groeit uit tot de beweging bij uitstek die de normalisering van de seksualiteit aanvecht.

De 'zelfproductie' van identiteit via seksualiteit is door de homobeweging begin jaren tachtig in militante zin opgenomen - weaponized, in huidige termen. Zoals de kraakbeweging het recht op wonen naar eigen wens en inzicht materieel en militant vormgaf, zo deed de homobeweging dat met seksualiteit. De meest radicale bevestiging daarvan vindt plaats tijdens de aidscrisis die in dezelfde tijd ontstaat. Huub Dijstelbloem heeft in zijn proefschrift beschreven hoe - toen aannemelijk werd dat er een verband bestond tussen de verspreiding van het nieuwe virus en de seksuele praktijken van homoseksuele mannen - de militante homobeweging het voornemen van de bloedbanken om uit voorzorg alle homoseksuele mannen als donors te weigeren als 'discriminatie' wist te brandmerken. Het zou immers niet gaan om homoseksualiteit als zodanig, maar om de praktijk van wisselende partners (Dijstelbloem 2008, 124). Dat laatste was wel een heel versluierende formulering voor een escalerende praktijk van emancipatoire overmoed en onverschillige agressie. Zoals Roel Coutinho, destijds hoofd infectieziekten bij de Amsterdamse GGD, memoreert in een recent interview, was de eerste patiënt die eind 1981 in Nederland werd opgenomen, een man van 42 die met honderden mannen seks had gehad en daarbij 25 keer gonorroe had opgelopen en drie keer syfilis (Coutinho 2020). Dat illustreert letterlijk en figuurlijk hoezeer een 'fuck you'-mentaliteit al tot basis van identiteitspolitiek was geworden.

Dit was de exponent, en resultante, van een opvallende en door niemand zo bedoelde ontwikkeling. Identiteitspolitiek vond haar oorsprong in een soort 'geuzenpolitiek': men vond een stem juist vanuit de ervaring een stem te worden ontzegd, door de heersende machten. Men 
komt op voor het recht om niet te worden gestereotypeerd. Deze op zichzelf emancipatoire dynamiek ontspoort echter wanneer een ostentatief en militant zich afzetten tegen de 'gevestigde orde', of die nu politiek, biologisch of beide is, tot doel op zichzelf wordt. Hiermee verkeert het credo van Foucault - laat het vaststellen van onze identiteit maar aan de politie over - in zijn tegendeel en komt er zoiets als een vrijwillige identiteitspolitie tot ontwikkeling, in het leven geroepen door de radicale identiteitsbevrijders zelf. Het inzicht dat identiteit iets is dat de autoritaire vijand je oplegt, is omgeslagen in de idee dat je een eigen identiteit moet claimen om van daaruit vijanden te identificeren. We zien dit vandaag de dag terug in de politieke correctheid, die bij links evenzeer heerst als bij rechts, en uiteindelijk weinig meer inhoudt dan het koesteren van een eigen identiteitsvocabulaire, en daarbij anderen te manen zich hiernaar te voegen, op straffe van een aanklacht wegens discriminatie of disrespect.

Dit is een probleem dat zich heeft ontvouwd in de afgelopen veertig jaar, de looptijd dus van Krisis. De kiem ervan zien we al in miniatuur in de geciteerde passage uit Archéologie du savoir, waar Foucault begint met uit te leggen dat hij via zijn werk de vraag naar zijn eigen identiteit hoopt te kunnen verdagen, maar eindigt met een sneer naar de politie aan wie 'we' het vaststellen van 'onze' identiteit maar moeten overlaten. Kennelijk concipieert Foucault hier de identiteitsweigering of - verdaging toch ook als een collectief project - een project dat, ironisch genoeg, een zekere (groeps)identiteit kan verschaffen. In ieder geval spreekt hij een publiek aan dat hij hoopt hiermee te begeesteren.

Het lijkt mij aannemelijk dat Foucault hier aanvankelijk alleen beoogde een primair privaat project aan te duiden dat eenieder zou kunnen entameren, een 'ethisch' project dat erop is gericht zich te kunnen onttrekken aan institutionele en ideologische dwangstructuren en dat dus een quasi-anarchistisch project is. Ik bedoel ethisch hier in de betekenis die Foucault daar zelf aan geeft in zijn bekende voorwoord bij de Engelse vertaling van L'Anti-Oedipe uit 1977. Hij noemt dit "het eerste boek over ethiek in lange tijd", waarbij met ethiek wordt bedoeld 'hoe te vermijden fascist te worden, ook (en vooral) wanneer je meent een militante activist te zijn.' (Deleuze \& Guattari 1977, xiii) Dit is een uitstekend inzicht, en behoort tot de weinige werkelijk zinnige uitspraken over ethiek.

Foucault probeert zich aan zijn eigen ethische gebod te houden door zijn genealogie niet te concipiëren als een handboek voor machtsuitoefening, maar als een 'analytica van macht'. Die 
analytica is haast een logica, die weinig of geen correspondentie meer vertoont met menselijk zelfbegrip of zelfwaardering, en er zelfs op gericht is deze radicaal te bekritiseren en ondermijnen. Het is de logica van de oorlog: de strijd om onderwerping en dominantie, die niet meer gericht is op erkenning, maar alleen in nietzscheaanse categorieën van superioriteit en inferioriteit kan worden uitgedrukt.

De vraag is al vaak gesteld of Foucaults eigen praktijk als activist en pamflettenschrijver hiermee wel in overeenstemming kan zijn. Bijvoorbeeld zijn betrokkenheid bij de GIP, de Groupe de l'Information sur les Prisons. Dat is een mede door Foucault opgericht gezelschap met een maoïstische oriëntatie, zoals dat alleen in die tijd kon. De feitelijke activiteiten van de GIP waren zodanig dat ze ook vanuit liberaal perspectief prima gelegitimeerd zouden kunnen worden. Men organiseerde immers geen gewapende opstanden of gewelddadige bevrijdingsacties, maar informeerde de publieke opinie over wantoestanden in de Franse gevangenissen. Zo'n liberale uitleg is echter in strijd met de uitgangspunten van de genealogie, die stelt dat machtsrelaties betrekking hebben op oorlogvoerende krachten, in plaats van op een politieke eenheid die is gebaseerd op (de overdracht van) rechten en soevereiniteit (Hoffman 2007, 764).

Het antwoord moet dus zijn: nee, die overeenstemming was er niet, en kon er niet zijn. Politiekfilosofisch geformuleerd: uit de genealogische analyse vloeit onvermijdelijk voort dat betrokkenheid als die van Foucault eerder moet worden begrepen als een vorm van burgeroorlog dan als een vorm van politiek engagement. Foucault kwam ook zelf tot die conclusie: "L'exercice quotidien du pouvoir doit être considéré comme une guerre civile." Of zoals hij het iets later uitdrukte, in een fameuze omkering van Clausewitz: "politiek is de voortzetting van oorlog met andere middelen" (Hoffman 2007, 761). Als activist was Foucault dus zeker betrokken bij machtsuitoefening, al zal hij nog steeds hebben gemeend dat het doel daarvan was om te voorkomen dat de uitoefening van macht geïnstitutionaliseerd raakt. We zouden dit een project van 'opschorting van de macht' kunnen noemen.

Als individueel project is hier, denk ik, nog steeds veel voor te zeggen, maar als collectief project is het gesneefd. De belangrijkste reden daarvoor is dat identiteitsweigering als collectief project niet mogelijk is. Mobilisatie van mensen (zoals in actiegroepen en sociale bewegingen) moet altijd geschieden onder enige noemer. Of beter gezegd, zulke mobilisatie produceert zelf onvermijdelijk zo'n noemer. Het is de activiteit zelf die de overtuiging en de 
identiteit creëert. Zo niet, dan is de macht 'vergeven' en gaat de beweging roemloos ten onder. Het is immers niet mogelijk - of zinloos - om strijd te blijven voeren zonder noemer waaronder je dat doet, of zonder een idee van een gemeenschappelijke noemer waaronder je de confrontatie aangaat. Strijd voert men onder een vaandel.

Mobilisatie en identiteit zijn meer dan alleen feitelijk onvermijdelijk verbonden. Die verbondenheid heeft ook een normatief belang: ze maakt mogelijk dat strijd resulteert in emancipatie. Emancipatie is precies het proces waarin individuen leren hoe ze zich individueel kunnen vormen door zich aan externe machten te onttrekken, terwijl (en doordat) ze tegelijkertijd zich collectief identificeren en solidair zijn met anderen. Pas onder die omstandigheden kan de republikeinse politieke droom van collectieve macht als vergrote vorm van individuele macht worden verwerkelijkt - een droom die we expliciet bij Arendt en impliciet bij Foucault vinden. Het republikeinse project verandert dan in een project van mondige burgers, die niet alleen de strijd voeren maar ook in staat zijn om uit die strijd lering te trekken.

De belangrijkste les vanuit Habermasiaans perspectief is hoe de pluraliteit aan identiteiten institutioneel te accommoderen. Daarvoor is een leerproces nodig bij de burgers die vanuit hun uiteenlopende identiteiten met elkaar in botsing komen, en als verdere institutionele achtergrond daarvan een democratische rechtsstaat, die in geval van conflictescalatie tussen identiteiten in staat is om te interveniëren via democratisch-procedureel geregelde escalatie, in het ultieme geval al dan niet met gewelddadig politioneel ingrijpen.

Foucaults ideaal hier was, lijkt mij, om door het weigeren van identiteit zo ongrijpbaar mogelijk te worden voor de politie en haar symbolische of feitelijke geweld. Zijn idee van een ethos lijkt mij erop gericht om de 'consolidatie', en daarmee de mogelijke 'solidarisering', van identiteiten tegen te gaan, en daarmee ook de mogelijkheid van een escalerend conflict tussen zulke identiteiten. Het onvermijdelijke proces van een zich in de mobilisatie en bewustwording vormende identiteit wordt als het ware gecompenseerd, of weer ongedaan gemaakt, door het genealogische inzicht dat het hier gaat om contingente bezweringen van machtsprocessen waarin niets anders telt dan strijd, onderwerping en overwinning. Wat het ethos van de tijdelijke, fragmentarische identiteit ons kan bieden, is dat we als het ware weer voor even de dans ontspringen - de dans der disciplinerende machten, de structuren die ons beheersbaar, berekenbaar en productief maakt. 
Maar de identiteitspolitiek heeft zich in feite in tegenoverstelde richting ontwikkeld. Identiteit wordt veelal gekoppeld aan een vermanend spreken over macht - dat daardoor niet meer genealogisch genoemd kan worden - zodat het kan worden ingezet als wapen in de politieke strijd. Misschien is dit vooral een reactie op de accommoderende tendens van bestuur en instituties, die juist wel een habermasiaans leerproces hebben ondergaan in de jaren zeventig en tachtig. Of anders gezegd, identiteitspolitiek is een reactie op het succes van de 'lange mars door de instituties'; die instituties zijn op een gegeven moment iets te responsief geworden, in zekere zin een nieuwe vorm van repressieve tolerantie. In zoverre er een leerproces bij de emanciperende groepen is opgetreden, is ook dit in tegenovergestelde richting gegaan: men heeft geleerd om juist via identiteit het conflict op te zoeken, en voor de geproclameerde kwetsing van de identiteit genoegdoening te eisen.

Dit is nog het beste te zien in de huidige tendens naar politieke correctheid, die we de politionele vorm van identiteitspolitiek zouden kunnen noemen. Niet alleen is het leerproces hier getransformeerd tot een 'proces van belering' van anderen - 'ook jij profiteert van de huidige en vroegere uitbuiting van minderheden!' - het is ook vermanend, bewakend en bestraffend geworden, en daarmee dus politioneel. Het 'vaststellen van de identiteit' wordt hiermee inderdaad 'aan de politie overgelaten', maar met dit verschil dat men zich intussen zelf de rol van de politie heeft aangemeten. Ironisch genoeg is de werkelijke politie in de afgelopen decennia juist veel meer communicatief en bemiddelend gaan optreden, waar de politiserende avantgardes van de geesteswetenschappen zich steeds meer politioneel zijn gaan opstellen.

Hiermee dreigt het spanningsveld zoals zich dat ten tijde van de oprichting van Krisis in de geesteswetenschap vormde tussen Habermas en Foucault te evolueren tot een improductieve stand-off, een patstelling, waarin spreekrechten - en met name spreekverboden voor de tegenpartij - steeds nadrukkelijker worden gekoppeld aan identiteitsclaims. Dat spanningsveld had altijd al de potentie om een mijnenveld te worden. Zo is de redactie van een geestverwant Amerikaans filosofisch tijdschrift enkele jaren geleden zowat ontploft toen het tijd was om een nieuwe editor te benoemen en de redactieraad radicaal verdeeld bleek - in een crisis belandde - over de vraag of de kandidaat meer Habermasiaans georiënteerd moest zijn of meer poststructuralistisch, Foucaultiaans geïnspireerd. Koppen rolden en decennialange vriendschappen werden op het altaar van dit conflict geofferd. De politionele politieke correctheid lijkt dit 
immer op de loer liggende conflict nu 'op te lossen', dat wil zeggen voort te zetten, door het te bevriezen in een soort koude oorlog van elkaar belerende en bestraffende partijen. Dit lijkt mij een groter probleem dan de vermeende 'toxiciteit' van deze of gene opvatting of positie, een tegenwoordig vaak gebruikte term die zelf nogal Koude Oorlog-achtig aandoet (was het communisme ook niet toxisch?)

Ik denk dat Krisis destijds een goede greep heeft gedaan door zichzelf Krisis te noemen. Zij heeft de crisis, in dit geval die van de identiteitspolitiek, daarmee onmiddellijk tot thema van reflectie op haar eigen 'identiteit' gemaakt, en mede daardoor wellicht weten te voorkomen zelf door zo'n crisis te worden verrast. Ik geloof dat Krisis een behoorlijk evenwicht heeft weten te bewaren tussen zich begeven in de identiteitsoorlogen enerzijds - je moet je immers engageren met en verhouden tot de tijdgeest - en niet toegeven aan onredelijke verlangens van de betreffende partijen anderzijds. Krisis is in haar veertig jaar sterk maatschappelijk en politiek geëngageerd geweest, maar is nooit politiek correct of belerend geworden. Dat is een hele prestatie, en een felicitatie waard.

\section{Verwijzingen}

Coutinho, Roel \& Jannetje Koelewijn. 2020. "Net als iedereen dacht ik: het zal wel meevallen." NRC, 16 mei, 2020.

Deleuze, Gilles \& Félix Guattari. 1977. Anti-Oedipus. New York: Viking.

Dijstelbloem, Huub. 2008. Politiek vernieuwen. Amsterdam: Van Gennep.

Hoffman, Marcelo. 2007. "Foucault's Politics and Bellicosity as a Matrix for Power Relations." Philosophy \& Social Criticism 33 (6): 756-778.

van Oenen, Gijs. 2009 "Vrijstaat. Hoe Amsterdam in 1980 zijn onschuld verloor." De Witte Raaf 24 (september-oktober 2009): 1-3.

van Oenen, Gijs. “Tijd voor identiteit.” Krisis 77 (december 1999): 16-17.

van Oenen, Gijs ‘Het sociale als vinding', Krisis 15 (juni 1984): 93-95.

\section{Biografie}

Gijs van Oenen studeerde eind jaren zeventig en begin jaren tachtig politicologie aan de Universiteit van Amsterdam, promoveerde daar aan de juridische faculteit, en doceert sinds 1994 sociale en politieke filosofie aan de Erasmus Universiteit Rotterdam. Zijn meest recente boek is Overspannen democratie. Hoge verwachtingen, paradoxale gevolgen (Boom 2018). 